
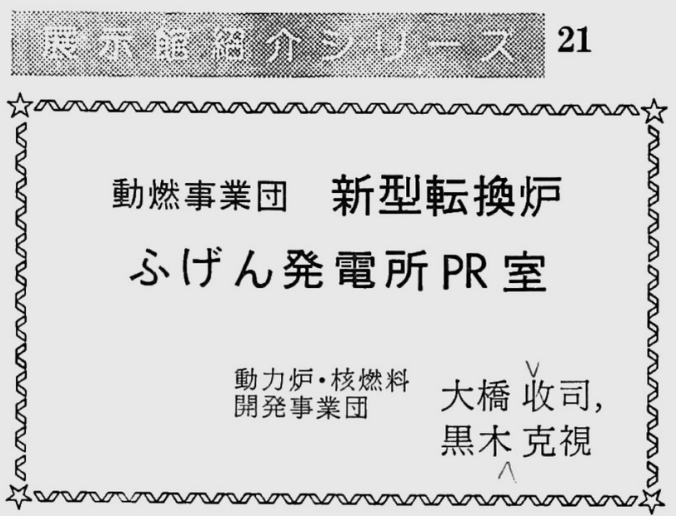

\section{I . はじめに一原型炉「ふげん」の 特徵之開室の経緯}

動力炉・核然料開発事業団(動然)の新型転換炉ふげ ん発電所は, ナショナルプロジェクトとして, 各界の 協力のもとに, 我が国が自主開発した重水減速沸腾軽 水冷却型(圧力管型)の発電プラントである。電気出力 は $165,000 \mathrm{~kW}$ で，昭和 45 年12月に着工し，同54年 3 月から本格運転を開始して順調に運転を続けている。

(写真 1)

新型転換炉は, 我が国が $\mathrm{Pu}$ の本格的早期利用を目 指して開発を進めている炉で，軽水炉の使用済燃料か ら再処理して回収される $\mathrm{Pu}$ を有効かつ容易に利用で き, 我が国のェネルギー・セキュリティの向上に寄与 するものとして位置づられている。

このような我が国の基本政策に沿って，昭和57年 8 月原子力委員会が，原型炬「ふげん」に続く実証炉(60 万 $\mathrm{kW}$ )計画について, 「実証师の建設・運転は, 電気事
業者及び動力炬・核燃料開発事業団の協力を得て電源 開発株式会社が行ら」との基本方針を決定しており, 現在設計が進められている。

「ふげん」の特徵としては，詳しくは他の諸資料にゆ だねたいが，我が国が設計から機器製作・建設・運転ま でをやり通した初の原子力発電プラントであること， 燃料には $\mathrm{Pu}$ 混合酸化物然料を装荷していること，さ らに減速材には中性子経済の良い重水を使用し, 高温 高圧の冷却材と常圧の減速材を分離した圧力管型であ ることなどである。特に本炉は，Pu燃料を本格的に使 用している世界で初の熱中性子発電炉として，各国か ら高い評価を受けている。

また「ふげん」に初装荷した混合酸化物然料には動燃 ・人形峠産の天然 U を使用したこと,さらに第 3 回取 替燃料からは動燃・再処理工場で軽水炉の使用済燃料 から抽出した $\mathrm{Pu}$ を使用した然料を装荷したことによ り，我が国の核燃料サイクルの輪が閉じたことなどす 特筆されることである。

ふげん発電所の PR 室は，このような「ふげん」の特 徵, 仕組み, 研究開発および建設の経過等の概況を，来 訪者によく知って頂き，ナショナルプロジェクトとし ての大事業の推進に理解と協力を得たいための切望か ら設置の運びとなったものである。

開室は, 昭和 53 年 5 月 15 日福井原子力センターで 「ふゲん臨界記念祝賀会」が行われた日であった。

\section{II . PR 室の概要と特色}

PR 室は，ふげん発電所正門に向ってすぐ右手，発 電所境界フェンスの外側の一段高いところに位置して いる。建物はふげん発電所建設当時の事務所を増改築

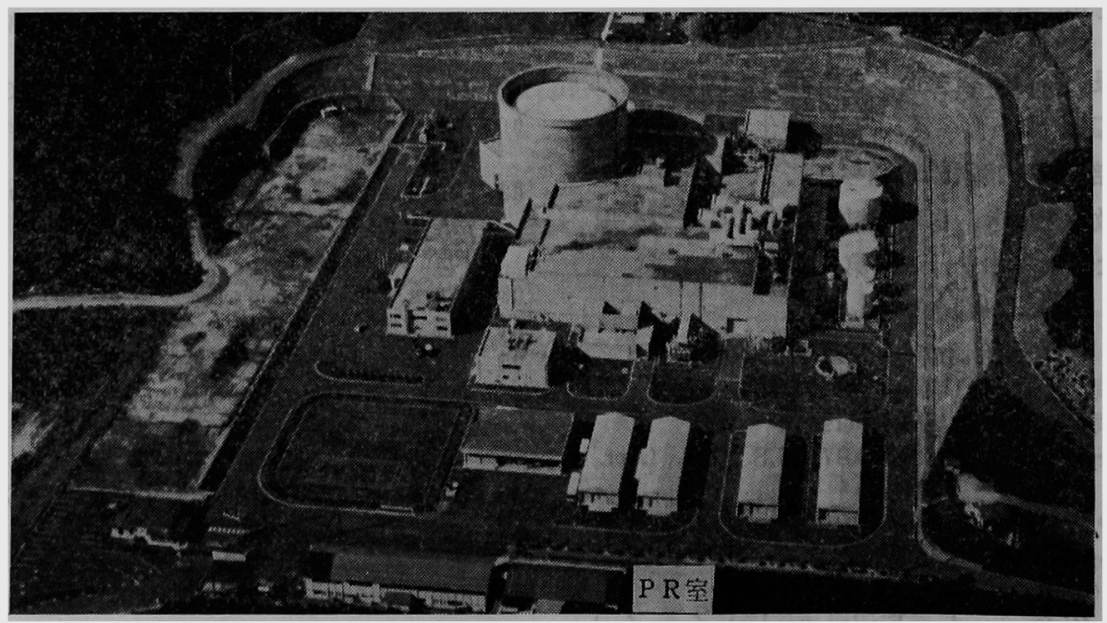

写真 1 ぶ゙ん発電所全景 
して完成した。建築面積は約 $370 \mathrm{~m}^{2}$, 前庭, 内庭を含め

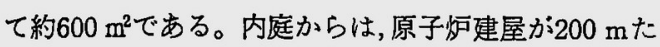
らずの近距離にあるので，説明には格好の場所といえ る。(写真 2 )

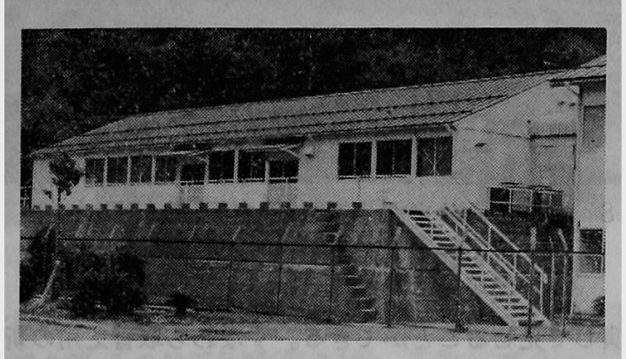

写真 2 発電所構内から見た PR 室外観

一般の来室者は正門前駐車場でハス等を降り，山沿 いの専用道路を約 $60 \mathrm{~m}$ 歩いて入口に達する。(写真 3 )

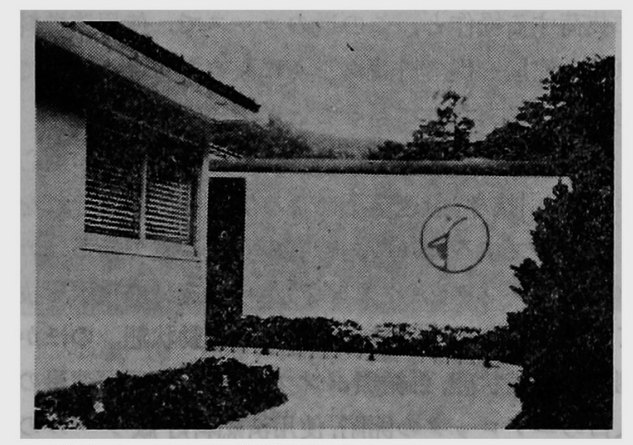

写真 3 PR 室玄関付近(壁の象マークは 「ふげん」のシンボルマーク)

建屋内部は, 映写集会室, 展示室 (Aと B)等からな っている。(第 1 図)

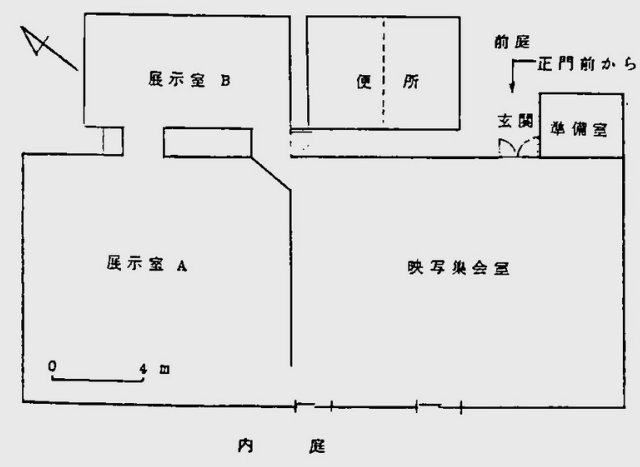

第 1 図 PR 室配置図

本 PR 室の特色は，原子力一般のものは他の諸機関 にゆずることとして，一言でいらと「ふげん」に関する ものだけが展示されているといらことであろう。
原子力開発では，まず優先されるものは「安全」であ るが，これは当然のこととして，ここでは説明,映画， VTR 拉よびオートスライド等の上映, 模型, 展示品, パ ネル等を通して「ふげん」に関する技術の開発がどのよ らになされたか、についての理解を深められるように 特に配虙されている。

ぶ゙ん発電所の PR 室は質素ではあるが，必要にし て十分なだけの PR 設備は整えられており，気楽に出 入りできるムードをたたえていると評されている。

\section{III. 各室の紹介}

\section{1. 映写集会室}

本室は収容人員約 70 名で, 団体等の一般説明やVT $\mathrm{R}, 16$ ミリ映画,オートスライド等の上映ができる。暗 幕は自動開閉式で, 概要説明用のパネルは正面映写幕 部の両側戸袋に収納され，説明時には引き出せるよう になっている。(写真 4 )

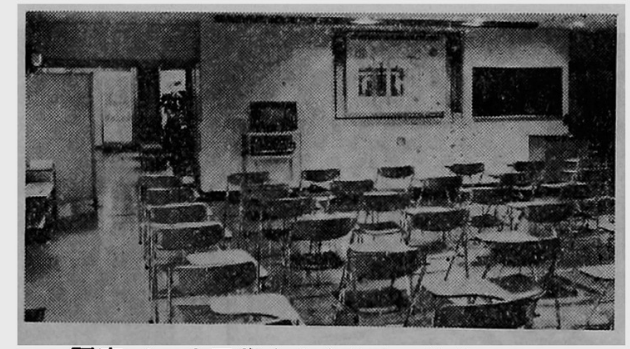

写真 4 映写集会室(正面が説明パネル， 左奥が展示室A)

主な説明パネルには次のるのがある。

「ふげん位置および周辺環境モニタリング図,構内 配置困, 建屋断面図(写真 5)，炉心説明図，燃料交換要 領説明図, 廃棄物処理系統図, 重水・ヘリウム系統図, 重

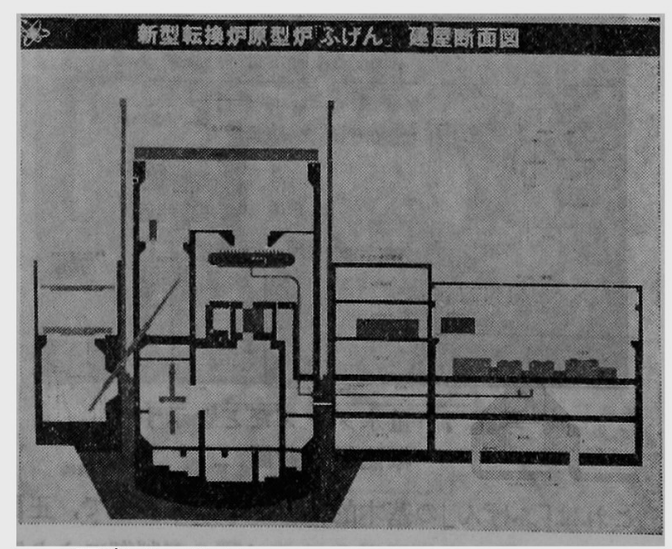

写真 5 説明パネル例(発電所建屋断面図) 
水精製装置, ふけ゚ん発電所系統図および核燃料 サイクルの仕組み等。

\section{2. 展示室}

内部は $\mathrm{A}, \mathrm{B}$ の 2 室に分けてあり， $\mathrm{A}$ 室は一 般向き，B室はややレベルを上げたレイアウト となっている。

(1) 展示室 $\mathrm{A}$

一般向きとして、「ふげん」の構造, シンボル の「普賢菩薩像」と「ふけ゚ん」の命名由来, 建設記 録, 初装荷燃料に用いた人形峠ウラン鉱石とそ の柴外線による䖝光発色箱, 燃料, 廃棄物処理, 放射線管理等の系統および中央制御室,タービン発電 機等がわかるカラーコルトン, 天科に載せられた重水, 遮蔽体の種類と放射線の関係がわかる実験セット等が 壁沿いに展示してある。

室の中央部には，本 $\mathrm{PR}$ 室最大の高さ $2.7 \mathrm{~m}$ ，幅 3.4 $\mathrm{m}$, 奥行 $2.0 \mathrm{~m}$ の原子炉機能模型が据え付けてある。

(写真 6, 7)

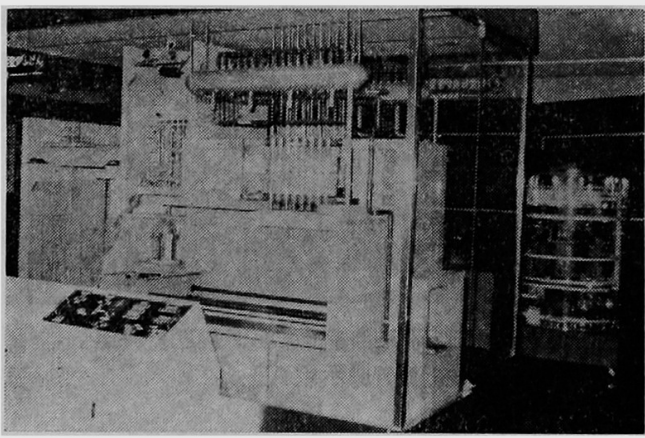

写真 6 燃料交換を示す機能模型正面(右側奥に 原子帅建屋内部模型が見える)

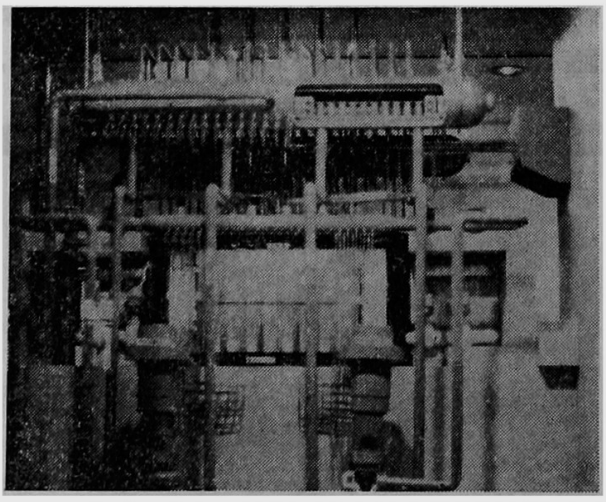

写真 7 重水ダンプなどを示す 機能模型背面

これは「ふゲん」の基本的仕組みの立体模型で, 正面 側では, 燃料交換の模様をコンピュータ制御により実

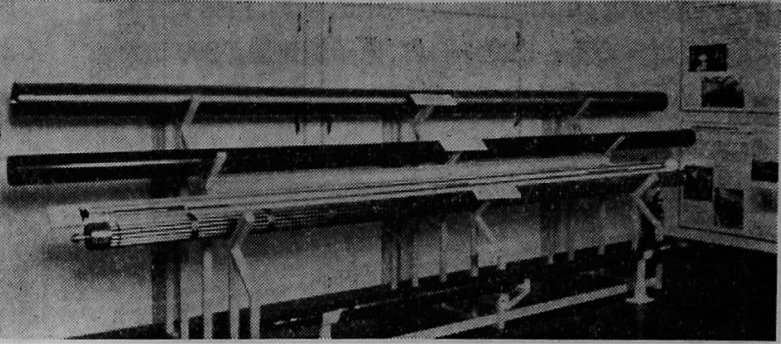

写真 8 上からカランドリア管, 圧力管, 燃料集合体 および下部遮蔽プラグ(右端壁に成果パネル の一部が見える）

演して見せることができる。すなわら取替え用の新然 料を, 燃料建屋から原子炉建屋内に運んで然料交換装 置に収め，操作者(見学者)が予め指定した炉心直下の 位置まで移動し，王力管(原子炉)(写真 8 )内の使用済 燃料を抜き取ったのち，運んできた新燃料を圧力管内 に装荷する操作と,この逆のコースで，使用済然料が 原子炉建屋を出て貯蔵プールに収容保管されるまでの 動きを目のあたりに見ることができる。

また背面では，押しボタン式により制御棒の炉心へ の插入,引抜き, 急速落下による炬の急停止とそれをバ ックアップする「ふげん」特有の安全装置である, カラ ンドリアタンク(炉心タンク)から減速材の重水を抜い て师を緊急停止する重水ダンプの作動状態, のほか計 測器の配備状態, 再循環ポンプの運転, 原子炉建屋の出 入口のエアロックの開閉, 使用済燃料貯蔵プールのラ ックの配列, 蒸気ドラムの断面構造等が良く理解でき るようになっている。

さらに側面では，蒸気タービンへ向ら配管や，主蒸 気隔離弁および給水配管の状態等もわかるよらになっ ている。

なお，この機能模型の側方奥には原子炉建屋内部の

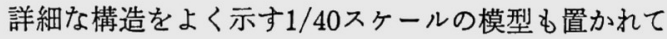
㧍り，内部構造の理解に役立っている。

(2) 展示室 B

ややレペルを上げて，「ふげん」の技術開発のために 本炉の特有構造に伴う重要開発項目について動然大洗 工学センター, 同東海事業所および他機関で行なった 研究開発, 実証試験等の成果を示すものを展示してい る。

すなわち, 炉心の主要構成部品のカランドリア管と 圧力管の実物と諸試験に使用した模擬燃料集合体や下 部遮蔽プラグ(写真 8 ), 燃料集合体の重要部品である スペーサの開発の歴史を示す数多くの試作品類(写真 9), 制御棒, 特殊燃料集合体内に組又込む材料試験片 


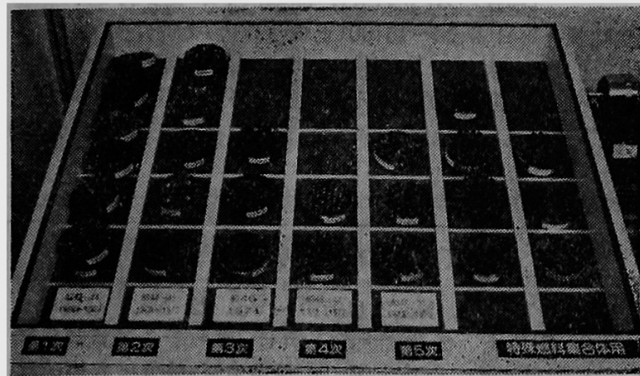

写真 9 スペーサの試作品類

を収めたキャプセル,カランドリア管および圧力管等 の接合部, その他部品類(写真10)，圧力管集合体の下 端部機構のシールプラグの着脱を手動で行える模型等 が置かれて拈り,「ふげん」の原理がよくわかるように なっている。

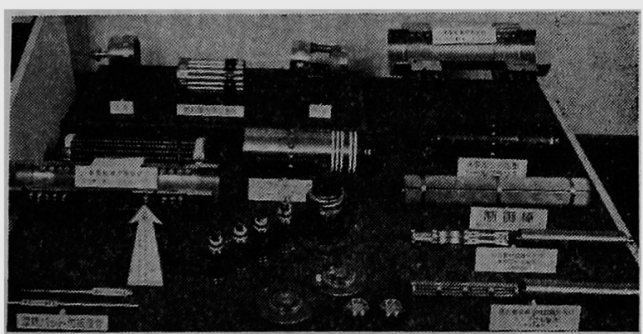

写真 10 制御棒, 材料試験片・キャプセル, カランドリア管および圧力管の 接合部, その他部品類

また壁面には，動燃その他の機関で行なった研究開 発の成果をまとめたパネルが多数掲げてある。標題の 例をあげると次のよらなものがある。

主蒸気隔離弁, $\mathrm{He}$ 連通弁, 重水ポンプ, シールプラグ の開発(写真11), 圧力管モニタリング装置の開発, 重水 臨界実験, 冷却材变失時の核的安全性, 燃料集合体の耐 久試験, 再冠水実験, 非常用驴心泠却系実験, 等々。

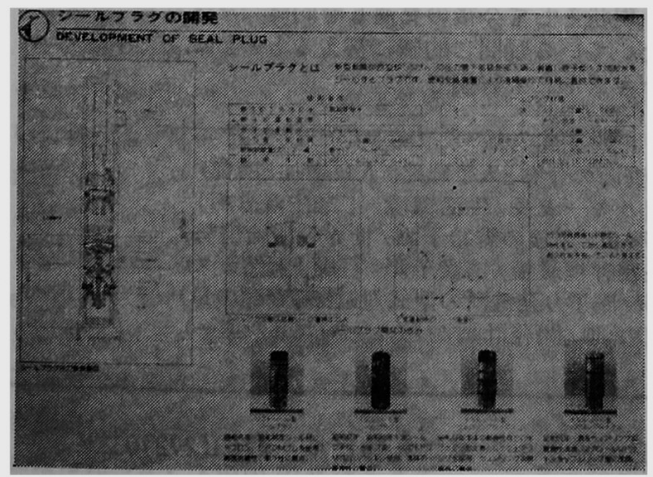

写真 11 成果パネル例(シールプラク゚の開発)
このようにこの室では「らケ゚ん」の技術開発にあた って特に重視し全力を傾注して取り組んだ実規模試験 装置による諸試験結果とその経過等がよくうかがえる ようになっている。

今後ここでは「らげん」の運転を通じて得られた新型 転換炉に関する知見やノウハウが着実に蓄積されてゆ く状態なども理解できるようにしたいと考えている。

\section{IV. 利 用 状 況}

本 $\mathrm{PR}$ 室も開室から既に満 4 年を経過した。来訪者 は，場所が北陸ということもあって，打のす゚と春から 秋に集中することは致し方ないとして，地元福井県内 はもとより全国各地から，また各界各層の人々が見え られている。原子力施設は初めてといら人ももちろん 多いが，軽水师は一応理解できたので，次は自主技術 開発のニューフェイスをと特に目指して来る人も少な くない。

外国からの来訪も多く, 第 2 回環太平洋会議, フィ ンランド原子力学会, 中国機械工業部代表団, メキシュ 電力庁総裁, ブラジル原子力委員会委員長 H. ガルバリ ョ氏, 現 IAEA 事務総長ブルックス氏, 台湾原子力委員 会委員長閻氏や, 英, 伊, 加, 日を主とする重水炉国際会 議(JUICE)の一行等々多彩であった。

これらは，前述の通り，「ふげん」が国際的にも注目 され高い評価を受けている証左でもあろう。

な怙本 PR 室が，当時の長田科学技術庁長官の記者 会見場となったことも記録されている。

\section{マ. おわりに}

以上の通り，ふげん発電所 $\mathrm{PR}$ 室は，「ぶげん」に関 するものだけが展示されていることもあり，他に比べ

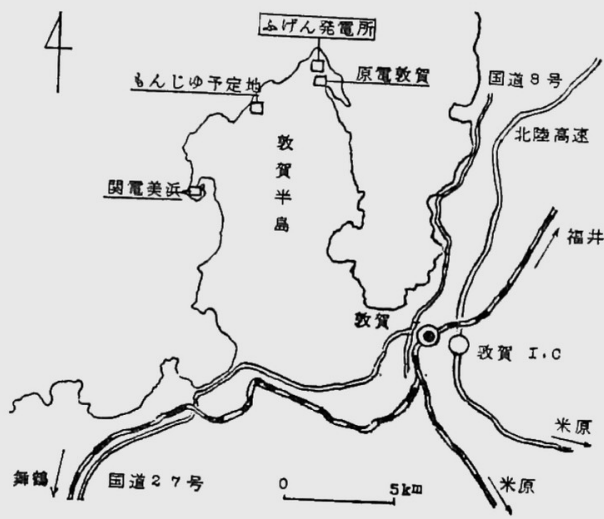

第 2 図敦贺半島付近案内図 
ていくぶん異なった感を持なれるかる知れないが，我 が国のナショナルプロジェクトとしての自主技術開発 の経過や师内構造等のよくわかる実物の展示品も多く 置かれているので, 来室者にはそれなりに満足して頂 けると思う。

幸いにして，隣接地には日本原子力発電㑣の敦賀原 子力館があり, ここでは沸滕水型, 加圧水型の両軽水 炬について良く設備されているので，「ふげん」との相 違, 比較等も容易である。

北陸路, 敦賀路においでの節は，ぜひごゆっくりと お立ち寄りを頂きたい。(第 2 図)

（1982年 12月20日 記）

○動然事業団ふげん発電所 PR 室O

所 在 地 (下914) 福井県敦賀市明神町 3 番地

交通機関 北陸本線敦賀駅からタクシーで約 30 分
（福鉄バス「立石」行，原電前下車 徒歩約 8 分）

開室時間 平日 9:00 16:00(土曜は12:00まで)

(休館日曜, 祝日,年末年始, $1 \cdot 3 \cdot 5$ 土㬈日)

問合せ先 新型転換师ふげん発電所総務課

(Tel. 0772-6-1221)

\section{「展示館紹介シリーズ}

1 12 Vol. 21, No. 2 (1979) Vol. 22, No. 1 (1980) 1. 原研 JRR-1，2. 動然大洗工学センター， 3. 東電福島第 一, 4. 関電美浜, 5. 京大炉, 6. 原電東海·敦賀, 7. 中国龟 島根, 8. 九電玄海, 9. 中部電浜成, 10, 四国電伊方, 11. 茨 城原子カセンター, 能登原子カセンター

13 22 Vol. 24, No. 6 (1982) Vol. 25, No. 3 (1983) 13. 九電川内， 14. 福井原子力センター，15. 宮城県原子力 センター，16. 東笔新渴，17. 動燃東海, 18. 福島県原子力 センター, 19. 東北電女川, 20. 関電大飯, 21. 動然「ふげん」 (以後の予定) 22. 関電高浜

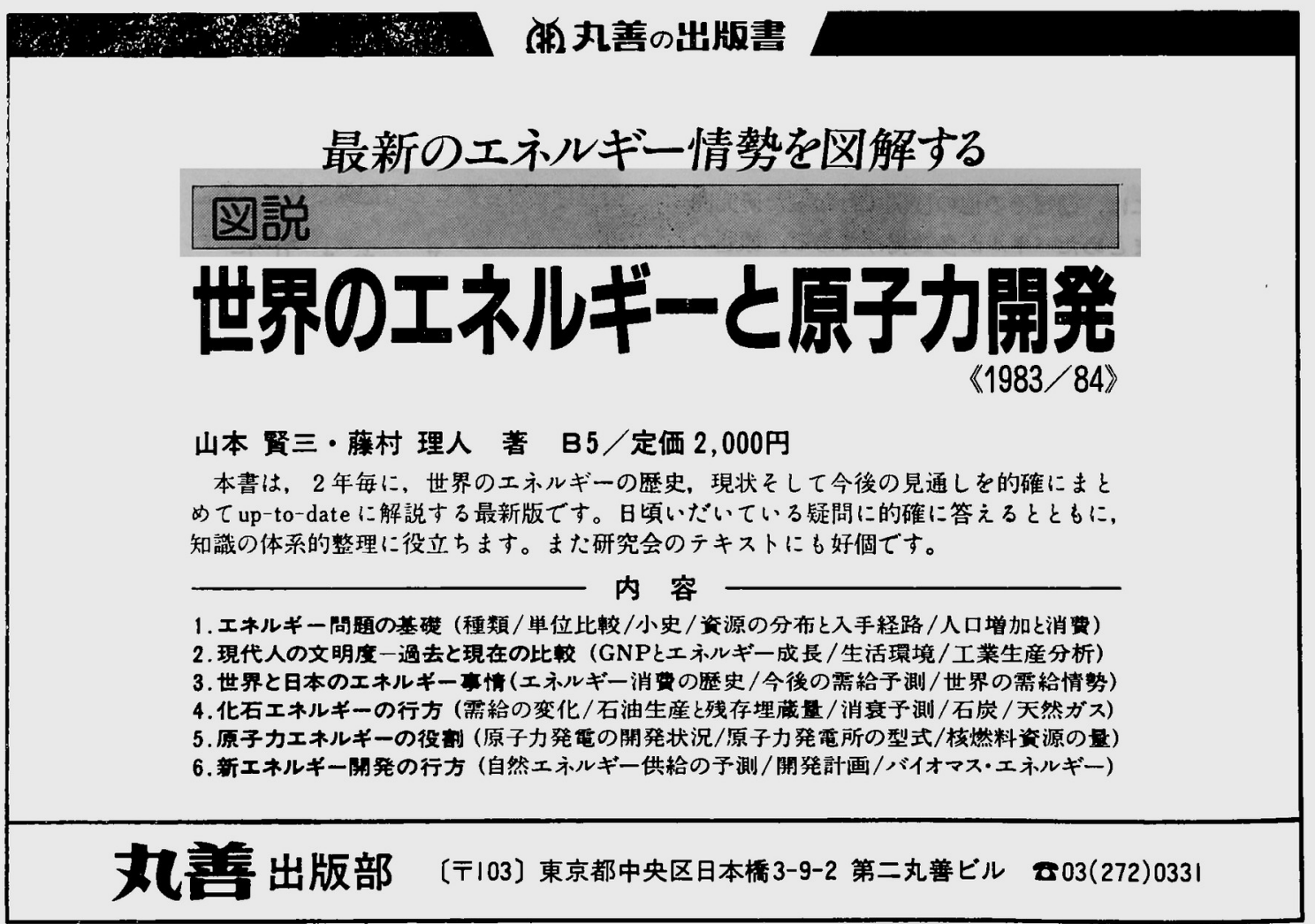

